\title{
Radiation-induced double strand breaks and subsequent apoptotic DNA fragmentation in human peripheral blood mononuclear cells
}

\author{
MYRIAM GHARDI ${ }^{1}$, MARJAN MOREELS ${ }^{1}$, BERNARD CHATELAIN ${ }^{2}$, \\ CHRISTIAN CHATELAIN $^{2}$ and SARAH BAATOUT ${ }^{1}$ \\ ${ }^{1}$ Radiobiology Unit, Molecular and Cellular Biology, Belgian Nuclear Research Centre, \\ SCK•CEN, B-2400 Mol; ${ }^{2}$ Laboratory of Experimental Hematology and Oncology, \\ UCL Mont-Godinne University Hospital, B-5530 Yvoir, Belgium
}

Received September 29, 2011; Accepted November 2, 2011

DOI: $10.3892 / \mathrm{ijmm} .2012 .907$

\begin{abstract}
In case of accidental radiation exposure or a nuclear incident, physical dosimetry is not always complete. Therefore, it is important to develop tools that allow dose estimates and determination that are based on biological markers of radiation exposure. Exposure to ionizing radiation triggers a large-scale activation of specific DNA signaling and repair mechanisms. This includes the phosphorylation of $\gamma \mathrm{H} 2 \mathrm{AX}$ in the vicinity of a double-strand break (DSB). A DNA DSB is a cytotoxic form of DNA damage, and if not correctly repaired can initiate genomic instability, chromosome aberrations, mutations or apoptosis. Measurements of DNA DSBs and their subsequent repair after in vitro irradiation has been suggested to be of potential use to monitor cellular responses. The bone marrow and the blood are known to be the most radiosensitive tissues of the human body and can therefore be of particular importance to find radiation-induced biological markers. In the present study, changes in H2AX phosphorylation and apoptosis of irradiated human peripheral blood mononuclear cells (PBMCs) were analyzed. Freshly isolated PBMCs from healthy donors were irradiated with X-rays $(0.1,0.25,0.5,1,2$ and $4 \mathrm{~Gy})$. The phosphorylation of $\gamma \mathrm{H} 2 \mathrm{AX}$ was measured at different time points $(0,0.25,1,2,4,6$ and $24 \mathrm{~h})$ after irradiation. We detected a linear dose-dependency of $\gamma \mathrm{H} 2 \mathrm{AX}$ phosphorylation measured by $\gamma \mathrm{H} 2 \mathrm{AX}$ foci scoring using immunofluorescence microscopy as well as by $\gamma \mathrm{H} 2 \mathrm{AX}$ fluorescence detection using flow cytometry. Apoptosis was detected by measuring DNA fragmentation at different time points $(0,24,48,72,96 \mathrm{~h})$ after X-irradiation using DNA ladder gel electrophoresis. The
\end{abstract}

Correspondence to: Dr Marjan Moreels, Radiobiology Unit Molecular and Cellular Biology, Belgian Nuclear Research Centre, $\mathrm{SCK} \cdot \mathrm{CEN}, \mathrm{B}-2400 \mathrm{Mol}$, Belgium

E-mail: mmoreels@sckcen.be

Key words: DNA damage, DNA repair, DSB repair kinetics, apoptosis, $\gamma \mathrm{H} 2 \mathrm{AX}$, biodosimetry, ionizing radiation apoptotic DNA fragmentation increased in a dose-dependent manner. In conclusion, DNA DSBs and subsequent apoptotic DNA fragmentation monitoring have potential as biomarkers for assessing human exposure in radiation biodosimetry.

\section{Introduction}

The most critical lesion induced by ionizing radiation is the interruption of genome integrity by DNA double-strand breaks (DSBs), which represents potentially lethal damage to the cell (1-4). In response to DSB generation, histone $\mathrm{H} 2 \mathrm{AX}$, a subfamily of histone $\mathrm{H} 2 \mathrm{~A}$, is rapidly phosphorylated on Ser-139 $(\gamma \mathrm{H} 2 \mathrm{AX})$ by members of the phosphoinositide 3-kinase (PI3-K) family [ataxia telangiectasia mutated Rad3related (ATR), ataxia telangiectasia mutated (ATM)], and DNA-dependent protein kinase (DNA-PK) (5). The phosphorylation of thousands of molecules of $\mathrm{H} 2 \mathrm{AX}$ in the chromatin adjacent to the DSB site is one of the earliest known events in response to radiation-induced DSB (6). After DSB formation, cells activate DNA damage checkpoint pathways to stop cell division in order to repair the damage and promote survival of the cell. Proteins important in cell cycle arrest, such as p53 and checkpoint kinases 1 and 2, are activated by ATR and ATM kinases immediately after DSB induction $(2,7)$.

Antibodies to $\gamma$-H2AX allow the visualization of a 'focus' at the DSB site. Due to the ease of this visualization, measuring $\gamma \mathrm{H} 2 \mathrm{AX}$ has become a standard method for detecting the induction and repair of DNA DSB. Traditionally, these foci have been quantified using immunofluorescence microscopy. However, with increasing sample numbers, high throughput assays can be advantageous. Flow cytometry methods have been developed and are ideal for measuring $\gamma \mathrm{H} 2 \mathrm{AX}$ in a high number of cells. Besides detection of $\gamma \mathrm{H} 2 \mathrm{AX}$ foci by microscopy, the relative expression of $\gamma \mathrm{H} 2 \mathrm{AX}$ as measured by flow cytometry has been shown to be a useful and reliable indicator of DNA damage as well $(8,9)$.

Radiation-induced DSBs are repaired within a few hours following irradiation. Many proteins are involved in various stages of DSB repair (10-13) thereby accumulating in the 
region of $\gamma \mathrm{H} 2 \mathrm{AX}$. Their mutual interaction at the site of DSBs is crucial for correct repair (14).

The global response of a cell to DNA damage triggers multiple pathways involved in sensing DNA damage, activating cell cycle checkpoints and inducing DNA repair (15). However, when the damage is severe, cellular apoptosis can be induced.

Since both strands are damaged, DSBs are more difficult to repair compared to single base damage or single-strand DNA breaks. Generally, DSBs are assumed to be the most important lesion to induce apoptosis (16). For this reason all living organisms possess the ability to detect even a few, possibly a single DSB $(17,18)$ and communicate this information to the cell cycle. However, specific slowly repaired or unrepaired DSB may eventually be responsible for induction of apoptosis.

Human peripheral blood mononuclear cells (PBMCs), which constitute a sample of non-proliferating normal tissue cells in the G0 phase within the body, are obtained by minimally invasive means and the large numbers of cells can be serially obtained in a short time.

The purpose of this study is to evaluate $\gamma \mathrm{H} 2 \mathrm{AX}$ foci and radiation-induced apoptosis as biodosimeter candidates and to determine a possible consistency of data regarding radiationinduced DNA damage and the radio-induced apoptosis in terms of cytotoxicity. In the present study, we used the $\gamma \mathrm{H} 2 \mathrm{AX}$ staining to detect DNA-DSB in human lymphocytes irradiated in fluorescence microscopy and in flow cytometry. These experiments were performed at low, moderate and high doses $(0.1,0.25,0.5,1,2$ and $4 \mathrm{~Gy})$ of X-rays and the kinetics of $\gamma \mathrm{H} 2 \mathrm{AX}$ foci within $24 \mathrm{~h}$ after irradiation were studied to monitor the subsequent repair of radiation-induced DNA damage. Furthermore, radiation-induced apoptosis was assessed by the measurement of apoptotic fragmentation in irradiated PBMCs from $24 \mathrm{~h}$ until $96 \mathrm{~h}$ after irradiation.

\section{Materials and methods}

Sample collection. Blood samples were collected by venipuncture in EDTA-vacutainer tubes (Becton-Dickinson, Belgium) from healthy donors (non-smokers, 20-40 years of age) from whom informed consent was obtained prior to the experiments.

Isolation of peripheral blood mononuclear cells (PBMCs). PBMCs were isolated from volunteers' blood by gradient density centrifugation using Histopaque-1077 (Sigma-Aldrich, Belgium) according to the manufacturer's instructions. After washing in cold phosphate-buffered saline (PBS, Gibco, Belgium), the cells were resuspended at a density of $2 \times 10^{6} / \mathrm{ml}$ in culture flasks in RPMI-1640 medium (Gibco) supplemented with $10 \%$ fetal bovine serum (FBS, Gibco) and $1 \%$ penicillinstreptomycin (Invitrogen, Belgium). The cell suspension was maintained in an incubator at $37^{\circ} \mathrm{C}$ humidified with $5 \% \mathrm{CO}_{2}$ until irradiation.

In vitro irradiation, culture and harvesting. The cells were irradiated at room temperature with $0.1,0.25,0.5,1,2$ and 4 Gy of X-rays. The irradiation was performed with a Pantak HF420 RX machine operating at $250 \mathrm{kV}, 15 \mathrm{~mA}, 1 \mathrm{~mm} \mathrm{Cu}$ filtration and at a dose rate of $0.26 \mathrm{~Gy} / \mathrm{min}$ (SCK•CEN, Belgium). Non irradiated control samples were included under similar experimental conditions. After irradiation, cells were incubated $\left(37^{\circ} \mathrm{C}, 5 \% \mathrm{CO}_{2}\right)$ and further processed after different time points (from 15 min until 96 h). Biological endpoints included DSB repair $(\gamma \mathrm{H} 2 \mathrm{AX})$, internucleosomal DNA fragmentation (DNA ladder) and determination of the apoptotic index (TUNEL).

Measurement of $\gamma H 2 A X$ foci by immunofluorescence microscopy. At different time points $(0.25,4$ and $24 \mathrm{~h})$ after $\mathrm{X}$-irradiation, PBMCs, were cytospun on coverslips, airdried and fixed in $4 \%$ formaldehyde (Invitrogen,) in PBS. Unirradiated control samples were included as well. Coverslips were washed 3 times for $5 \mathrm{~min}$ in PBS, permeabilized for $5 \mathrm{~min}$ at room temperature with $0.2 \%$ Triton $\mathrm{X}-100$ in PBS containing $3 \%$ bovine serum albumin (BSA, Gibco), and then blocked in $3 \%$ BSA-PBS for $30 \mathrm{~min}$ at room temperature. Cells were thereafter incubated for $1 \mathrm{~h}$ at $37^{\circ} \mathrm{C}$ with a primary antibody (mouse anti-H2A.X, phospho (Ser139) monoclonal antibody, Abcam, UK) for $\gamma \mathrm{H} 2 \mathrm{AX}$ diluted (1:300) in 3\% BSA-PBS. The cells were washed 3 times with PBS and incubated with a secondary fluorescein isothiocyanate (FITC)-conjugated goat anti-mouse (Sigma-Aldrich) diluted 1:250 in 3\% BSA-PBS for $1 \mathrm{~h}$ at room temperature in the dark. After 3 washings in cold PBS, cells were mounted in a mounting medium (Vectashield ${ }^{\circledR}$ Mounting Medium, Vectashield, Vector Laboratories, UK) containing DAPI (4,6-diamidino-2-fenilindole), a counterstain for DNA.

The immunofluorescence images were captured with an automated Nikon TE2000E epifluorescence microscope, equipped with a $60 \mathrm{X}$ plan oil objective and an Andor Ixon EM-CCD camera. Images were processed by Andor IQ software (Adobe, San José, CA, USA). For each time point, at least 100 nuclei were analyzed. The quantitative analysis of the $\gamma \mathrm{H} 2 \mathrm{AX}$ foci was performed using ImageJ freeware $(\mathrm{NIH}$; Betheseda, MD, USA) by customised algorithms, as previously described (19)

Flow cytometry analysis and CD45-labeling of lymphocytes. After 2 washings with cold PBS, $10 \mu \mathrm{l}$ of diluted R-phycoerythrin (1:9 concentration with filtered PBS) coupled to the cyanine dye Cy5 (PECy5)-conjugated mouse antihuman CD45 (leukocyte common antigen, Ly-5) monoclonal antibody (BD Pharmigen, Belgium) were added to each sample and incubated at room temperature for $15 \mathrm{~min}$ in the dark. Cells were rinsed and resuspended in $500 \mu \mathrm{l}$ of cold PBS, and immediately acquired on a flow cytometer (FACSCalibur, BD Biosciences, Belgium), and then, analysed with the CellQuest software (BD Biosciences, Belgium). Lymphocytes were gated based on low side scatter and bright CD45 (BD Pharmigen) staining $(20,21)$ (Fig. 1A and B). Data acquisition was set to analyse 10,000 lymphocytes from a forward scatter (FSC) vs. side scatter (SSC) plot (Fig. 1A). The acquisition gate (region 'Lymphocytes') was set so that only lymphocytes were included for analysis.

$\gamma H 2 A X$ assay. At 0, 0.25, 1, 2, 4, 6 and $24 \mathrm{~h}$ after $\mathrm{X}$-irradiation, PBMCs were washed in PBS, prior to staining with the $\mathrm{H} 2 \mathrm{~A}$ $\mathrm{X}$ phosphorylation assay kit (Millipore, Belgium). PBMCs were fixed in $2 \%$ formaldehyde with $0.8 \%$ methanol on ice for $20 \mathrm{~min}$, permeabilized with $0.5 \%$ saponin, and incubated 
A

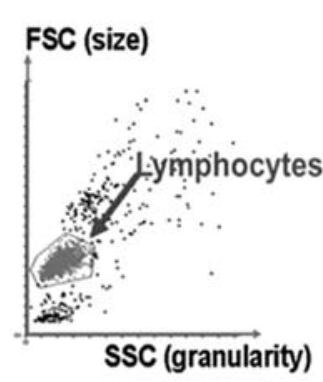

B CD45-PECy5

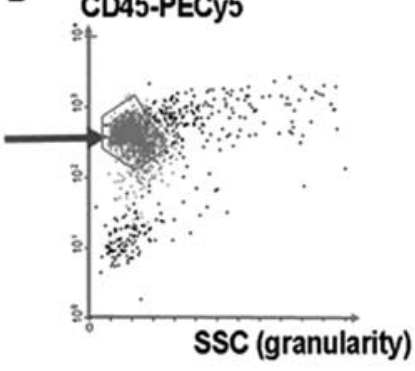

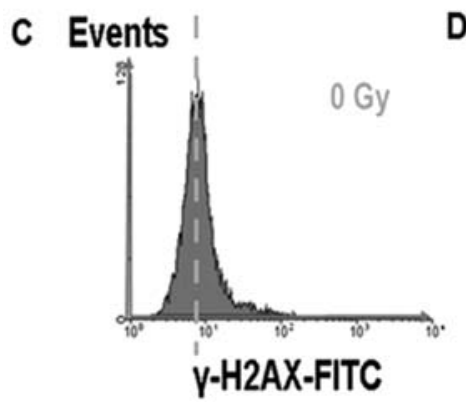

D Events

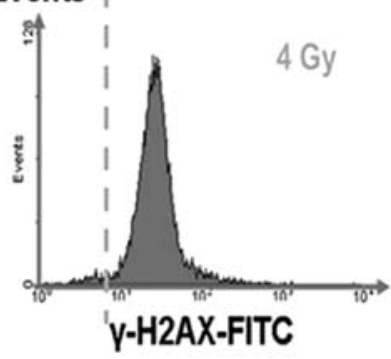

Figure 1. (A) Scatter plot of FSC vs. SSC in which lymphocytes were gated; (B) a representative dot plot of the CD45 expression demonstrating the selection of the lymphocytes. This population was used for further analysis; (C) representative histogram of $\gamma \mathrm{H} 2 \mathrm{AX}$ expression in non-irradiated lymphocytes; (D) representative histogram of $\gamma \mathrm{H} 2 \mathrm{AX}$ expression in irradiated lymphocytes $30 \mathrm{~min}$ after exposure to $4 \mathrm{~Gy}$ of X-rays. Note the clear shift in $\gamma \mathrm{H} 2 \mathrm{AX}$ expression compared to (C).

on ice for $20 \mathrm{~min}$ in the dark with FITC-conjugated mouse monoclonal anti-phospho-histone $\mathrm{H} 2 \mathrm{AX}$, according to the manufacturer's protocol. $\gamma \mathrm{H} 2 \mathrm{AX}$ phosphorylation was measured by assessing the level of intracellular fluorescence characterized in lymphocytes, as determined by the mean intensity of the $\gamma \mathrm{H} 2 \mathrm{AX}$ positive lymphocytes (Fig. 1C and D).

DNA ladder. PBMCs were collected by centrifugation at different time points after irradiation $(0,4,24,48,72$ and $96 \mathrm{~h})$. Genomic DNA samples were isolated by using the high pure PCR template preparation kit (Roche, Belgium). Cells were resuspended in binding buffer and ethanol, and were rinsed prior to the elution of purified DNA. For each sample, the same amount of DNA (200 ng) was loaded on a $1.5 \%$ agarose gel containing $0.5 \mu \mathrm{g} / \mathrm{ml}$ ethidium bromide. Electrophoresis was performed at $2 \mathrm{~V} / \mathrm{cm}$ for $2 \mathrm{~h}$. The DNA in the gels was visualized under ultraviolet light and photographed using a Molecular Imager Gel Doc XR System (Bio-Rad Laboratories, Belgium). The DNA ladder (Fermentas, Belgium) contains bands ranging from 100 to $10,000 \mathrm{bp}$.

Measurement of the signal intensity on an electrophoresis gel with a DNA ladder was performed using the ImageJ software. All data were expressed as integrated density values (IDV). For each dose, the data from 3 different healthy volunteers were pooled for the determination of the IDV with the error bars representing standard error of the mean (SEM).

TUNEL assay. DNA fragmentation associated with apoptosis was detected by the TdT-mediated dUTP nick end labeling (TUNEL) technique using an in situ cell death detection kit (Roche, Belgium). Non-irradiated and irradiated PBMCs were cytospun on coverslips and fixed in $4 \%$ paraformaldehyde in PBS after different time points $(0,24,48,72$ and $96 \mathrm{~h})$. After permeabilization with $0.1 \%$ Triton $\mathrm{X}-100$ and $0.1 \%$ sodium citrate (Sigma-Aldrich), cells were incubated at $37^{\circ} \mathrm{C}$ for $1 \mathrm{~h}$ in a humid chamber with TUNEL mixture containing terminal deoxynucleotidyl transferase (TdT) and FITC-dUTP, as recommended by the manufacturer's instructions. Finally, cells were mounted with a mounting medium containing DAPI for DNA counterstaining. The slides were subsequently analyzed by epifluorescence microscopy using an automated Nikon Eclipse Ti microscope equipped with a 20X plan dry objective, and imaged with a Nikon Digital Sight DS-QiMc camera. The images were processed by imaging software NIS-elements (Adobe).

The total number of cells (measured as DAPI ${ }^{+}$nuclei) or the number of TUNEL-positive cells in each field was determined. The apoptotic index (\% apoptosis) defined as the percentage of TUNEL-positive apoptotic nuclei divided by the number of total cells (DAPI ${ }^{+}$nuclei) was quantified with the ImageJ software through customized algorithms. A minimum of 100 nuclei from each condition were counted to generate a mean apoptotic index (AI).

Statistics. All experiments with quantitative analysis included data from at least 3 independent experiments. Data from 3 healthy volunteers were pooled and were expressed as mean \pm SEM, and statistical differences $(\mathrm{P}<0.005)$ at different doses and times after irradiation were determined with analysis of variance (ANOVA) and the paired t-test.

\section{Results}

DSB induction in irradiated lymphocytes analyzed by flow cytometry. The radiation-induced DSBs and repair analysed by flow cytometry in irradiated lymphocytes, is represented in Fig. 2. The error bars in the figure represent the SEM based on the interindividual variation among the 3 donors. A time- and 


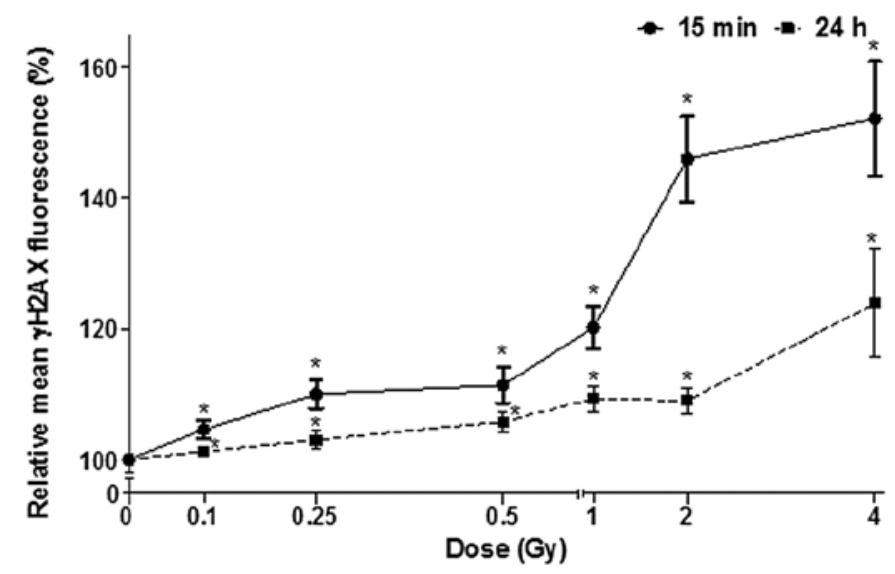

Figure 2. Dose-response curves of lymphocytes from 3 donors analyzed by flow cytometry $15 \mathrm{~min}$ and $24 \mathrm{~h}$ after X-irradiation. The response curves represent the relative mean $\gamma \mathrm{H} 2 \mathrm{AX}$ fluorescence as a function of the irradiation dose. Relative mean of $\gamma \mathrm{H} 2 \mathrm{AX}$ fluorescence was calculated by dividing the mean fluorescence of irradiated cells by the mean fluorescence of non-irradiated cells, so that the response at 0 Gy was equal to $100 \%$. Error bars represent \pm SEM $(n=3) .{ }^{*} \mathrm{P}<0.05$, statistically significant differences in comparison with the control conditions.

A

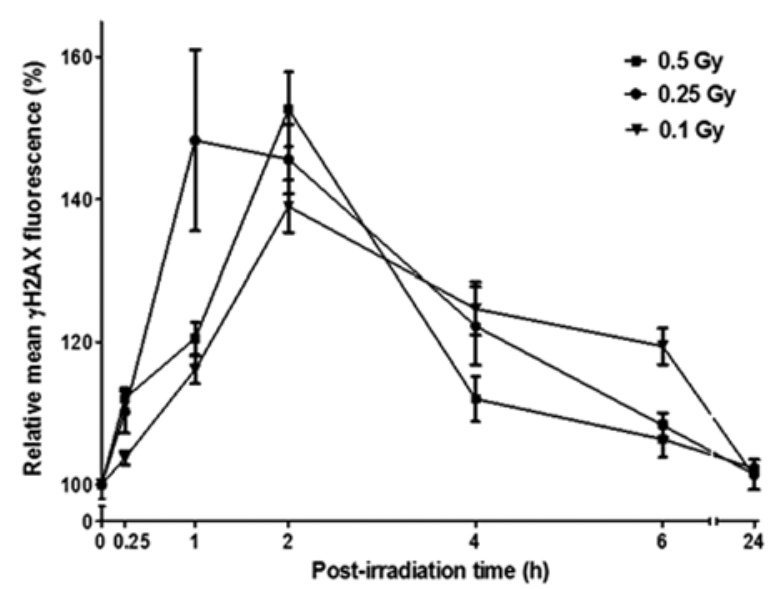

B

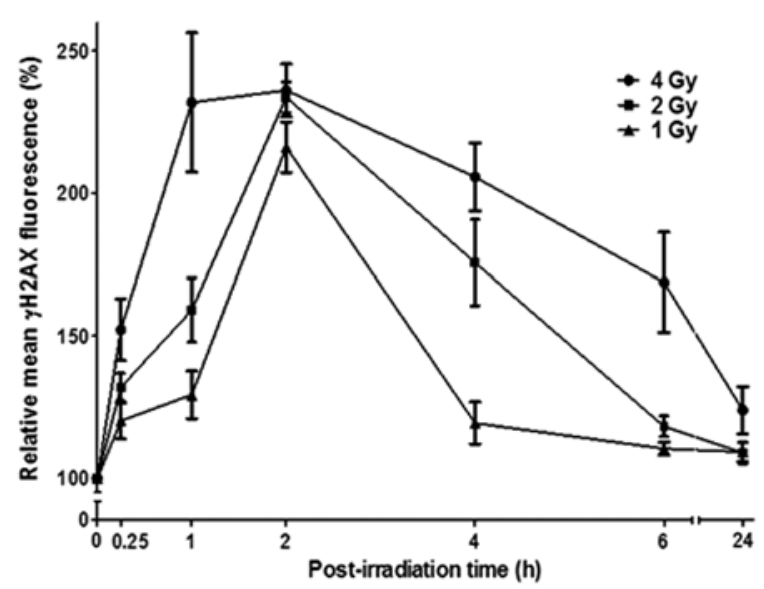

Figure 3. Kinetics of $\gamma \mathrm{H} 2 \mathrm{AX}$ formation in lymphocytes after X-irradiation measured by flow cytometry. Relative mean $\gamma \mathrm{H} 2 \mathrm{AX}$ fluorescence was calculated by dividing the mean fluorescence of irradiated cells by the mean fluorescence of unirradiated cells, so that the response at 0 Gy was equal to $100 \%$. Timeresponse curves representing the relative mean fluorescence of $\gamma \mathrm{H} 2 \mathrm{AX}$ at different time points after irradiation with (A) low and moderate doses $(0.1,0.25$ and $0.5 \mathrm{~Gy})$ or (B) at high doses (1, 2 and $4 \mathrm{~Gy})$. Error bars represent \pm SEM (n=3).

dose-dependency in the $\gamma \mathrm{H} 2 \mathrm{AX}$ response was shown (two-way ANOVA, $\mathrm{P}<0.001)$. An increase in $\gamma \mathrm{H} 2 \mathrm{AX}$ phosphorylation was measured $15 \mathrm{~min}$ after irradiation. Twenty-four hours after irradiation, a significant decrease of the $\gamma \mathrm{H} 2 \mathrm{AX}$ phosphorylation signal due to the subsequent repair in cells was observed (paired t-test, $\mathrm{P}<0.001$ ). The dose-effect relationship in $\gamma \mathrm{H} 2 \mathrm{AX}$ response showed a significant increase in the dose range from $0.1 \mathrm{~Gy}$ until $4 \mathrm{~Gy}$ (paired t-test, $\mathrm{P}<0.001$ ). At high doses (1, 2 and $4 \mathrm{~Gy}$ ), the $\gamma \mathrm{H} 2 \mathrm{AX}$ phosphorylation levels were significantly higher compared to low and moderate doses $(0.1$, 0.25 and $0.5 \mathrm{~Gy}$ ) for both time points.

Regression analysis was used to fit the data of $\gamma \mathrm{H} 2 \mathrm{AX}$ phosphorylation response and showed a dose-linear dependency, slopes being (in \%/Gy), $15 \mathrm{~min}$ and $24 \mathrm{~h}$ after irradiation, respectively, $13.39 \pm 2.095\left(\mathrm{r}^{2}=0.890, \mathrm{P}<0.005\right)$ and $5.443 \pm 0.6010\left(\mathrm{r}^{2}=0.942, \mathrm{P}<0.001\right)$. For the earlier postirradiation time $(15 \mathrm{~min})$, the dose-response curve in the dose range (0-4 Gy) shows a steeper slope in comparison with the latter post-irradiation time $(24 \mathrm{~h})$ where radiation-induced DSB were mostly repaired.

Kinetics of formation and loss of $\gamma H 2 A X$ by flow cytometry. Flow cytometry was used to monitor the level of $\gamma \mathrm{H} 2 \mathrm{AX}$ in lymphocytes at different time points $(0.25,1,2,4,6,24 \mathrm{~h})$ after irradiation (0.1, 0.25, 0.5, 1, 2, 4 Gy of X-rays) (Fig. 3). A large interindividual variability in $\gamma \mathrm{H} 2 \mathrm{AX}$ levels was observed.

The levels of $\gamma \mathrm{H} 2 \mathrm{AX}$ show a time- and dose-dependent response after low and high dose irradiation (two-way ANOVA, $\mathrm{P}<0.001)$. The dose-dependency of the $\gamma \mathrm{H} 2 \mathrm{AX}$ signal showed a significant difference of $\gamma \mathrm{H} 2 \mathrm{AX}$ levels up to $24 \mathrm{~h}$ between low/moderate doses $(0.1,0.25$ and $0.5 \mathrm{~Gy})$ and high doses (1, 2 and 4 Gy) (paired t-test, $\mathrm{P}<0.001)$. The timecourse pattern did not differ appreciably among the different individuals for all dose ranges (Fig. 3). A maximum response of $\gamma \mathrm{H} 2 \mathrm{AX}$ levels was observed at 1 or $2 \mathrm{~h}$, which was followed by a gradual loss of $\gamma \mathrm{H} 2 \mathrm{AX}$ over the next $6 \mathrm{~h}$ and a slower 
A

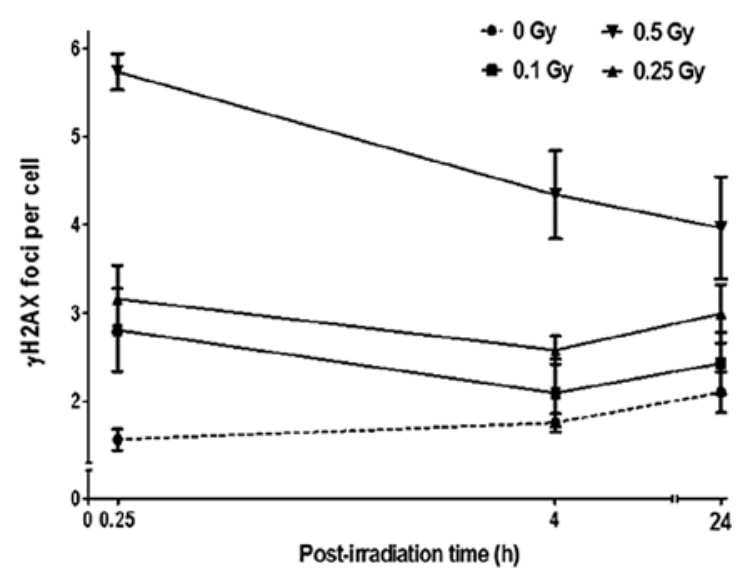

B

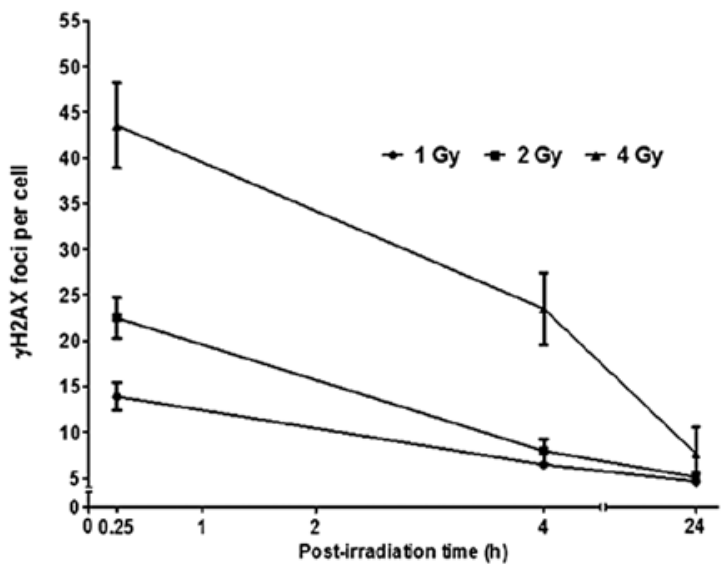

Figure 4. Kinetics of $\gamma \mathrm{H} 2 \mathrm{AX}$ foci formation in PBMCs analyzed by fluorescence microscopy. Time response curves represent the relative mean of $\gamma \mathrm{H} 2 \mathrm{AX}$ foci at different time points after irradiation. (A) Low and moderate doses (0.1, 0.25 and 0.5 Gy) or (B) high doses (1, 2 and 4 Gy) of X-irradiation. Error bars represent $\pm \operatorname{SEM}(n=3)$.

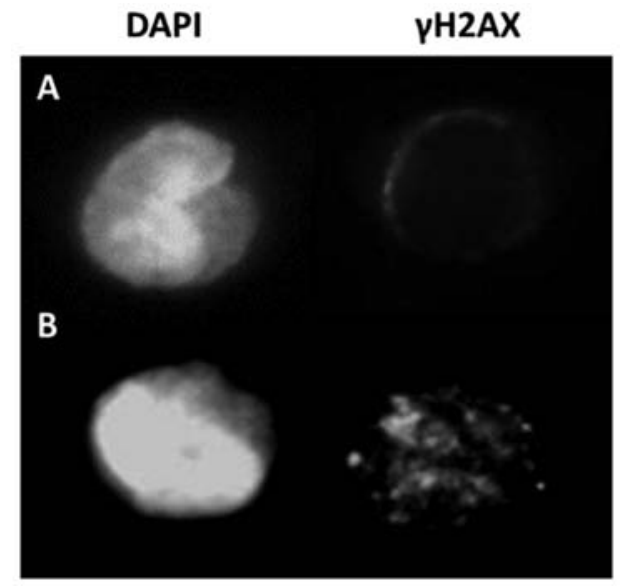

Figure 5. Representative images of PBMCs illustrating $\gamma \mathrm{H} 2 \mathrm{AX}$ foci formation, using immunofluorescence microscopy 15 min after X-irradiation. (A) Non-irradiated control; (B) irradiated PBMCs at 4 Gy (nuclei are countertained with DAPI).

decline until $24 \mathrm{~h}$ toward background levels (Fig. 3A). At 0.25 and $4 \mathrm{~Gy}$, the maximum response in $\gamma \mathrm{H} 2 \mathrm{AX}$ level was maintained for approximately $1 \mathrm{~h}$. The increase and decrease of $\gamma \mathrm{H} 2 \mathrm{AX}$ phosphorylation highlights respectively the induction and the subsequent repair of DSBs. After $24 \mathrm{~h}$, the $\gamma \mathrm{H} 2 \mathrm{AX}$ signal returned to background levels (Fig. 3A) at all doses, whereas after high doses $(1,2,4 \mathrm{~Gy})$, the $\gamma \mathrm{H} 2 \mathrm{AX}$ levels were significantly higher (Fig. 3B) compared to low doses $(0.1,0.25$, $0.5 \mathrm{~Gy}$ ). Besides a general response, inter individual variations in $\gamma \mathrm{H} 2 \mathrm{AX}$ levels were observed at various times following irradiation.

Kinetics of $\gamma H 2 A X$ formation after $X$-irradiation. The kinetics of $\gamma \mathrm{H} 2 \mathrm{AX}$ foci in PBMCs were analyzed by immunofluorescence microscopy. The presence of radiation-induced $\gamma \mathrm{H} 2 \mathrm{AX}$ foci in PBMCs was monitored by immunofluorescence microscopy at different time points $(0.25,1,2,4,6$ and $24 \mathrm{~h}$ ) after irradiation. Immunofluorescence microscopy of $\gamma \mathrm{H} 2 \mathrm{AX}$ revealed formation of nuclear foci in PBMCs after
$\mathrm{X}$-irradiation at low, moderate and high doses $(0.1,0.25,0.5,1$, 2 and 4 Gy) (Figs. 4 and 5). Representative images of $\gamma \mathrm{H} 2 \mathrm{AX}$ staining are presented in Fig. 5. For each of the curves, the data from 3 different healthy volunteers were pooled with the error bars representing SEM based on the interindividual variation among the donors.

The number of radiation-induced $\gamma \mathrm{H} 2 \mathrm{AX}$ foci showed a significant dose-dependency (two-way ANOVA, $\mathrm{P}<0.001$ ). The number of $\gamma \mathrm{H} 2 \mathrm{AX}$ foci number that was induced $15 \mathrm{~min}$ after X-irradiation, was significantly higher (fold-change $>4.5)$ at high doses (1, 2 and 4 Gy) compared to low and moderate doses $(0.1,0.25$ and $0.5 \mathrm{~Gy})$. Time-dependency in radiation-induced $\gamma \mathrm{H} 2 \mathrm{AX}$ foci was also shown (two-way ANOVA, $\mathrm{P}<0.001)$. Four hours after exposure, a significant decrease in the number of foci per cell was shown at all doses (paired t-test, $\mathrm{P}<0.001$ ). After 0.1 and $0.25 \mathrm{~Gy}$ exposure, the numbers of $\gamma \mathrm{H} 2 \mathrm{AX}$ foci per cell returned to background levels (Fig. 4A). However, at $24 \mathrm{~h}$, for doses higher than $0.5 \mathrm{~Gy}$, the number of $\gamma \mathrm{H} 2 \mathrm{AX}$ foci per cell was found to be significantly higher than in controls or in cells irradiated at $0.1,0.25$ and 0.5 Gy (Fig. 4B) (paired t-test, $\mathrm{P}<0.001$ ). Regression analysis did not show a linear dose- or time-dependent relationship in $\gamma \mathrm{H} 2 \mathrm{AX}$ foci disappearance (non-significant, $\mathrm{P}>0.3$ ).

Four hours after irradiation, 74, 81 and $75 \%$ respectively, of the initial number of $\gamma \mathrm{H} 2 \mathrm{AX}$ foci could still be detected after exposure to $0.1,0.25$ and $0.5 \mathrm{~Gy}$, whereas almost half of the initial number of $\gamma \mathrm{H} 2 \mathrm{AX}$ foci disappeared at 1,2 and $4 \mathrm{~Gy}$, respectively to 46,35 and $53 \%$. These data show a slower repair of the radiation-induced DSB at low and moderate doses $(0.1,0.25$ and $0.5 \mathrm{~Gy})$ in comparison with high doses $(1,2$ and 4 Gy). Twenty-four hours after irradiation, 86, 94 and $69 \%$ of the initial number of $\gamma \mathrm{H} 2 \mathrm{AX}$ foci remained respectively at 0.1 , 0.25 and 0.5 Gy whereas at 1, 2 and 4 Gy, respectively, 33, 22 and $17 \%$ of the initial number of $\gamma \mathrm{H} 2 \mathrm{AX}$ foci were detected. Within $24 \mathrm{~h}$ after $\mathrm{X}$-irradiation at low and high doses, the repair is slower than at $4 \mathrm{~h}$ and can be explained by the repair of most of the radiation-induced DSBs. The percentages of the initial number of $\gamma \mathrm{H} 2 \mathrm{AX}$ foci at $0.1,0.25$ and $0.5 \mathrm{~Gy}$ were significantly higher at $24 \mathrm{~h}$ compared to $4 \mathrm{~h}$ post-irradiation 
A

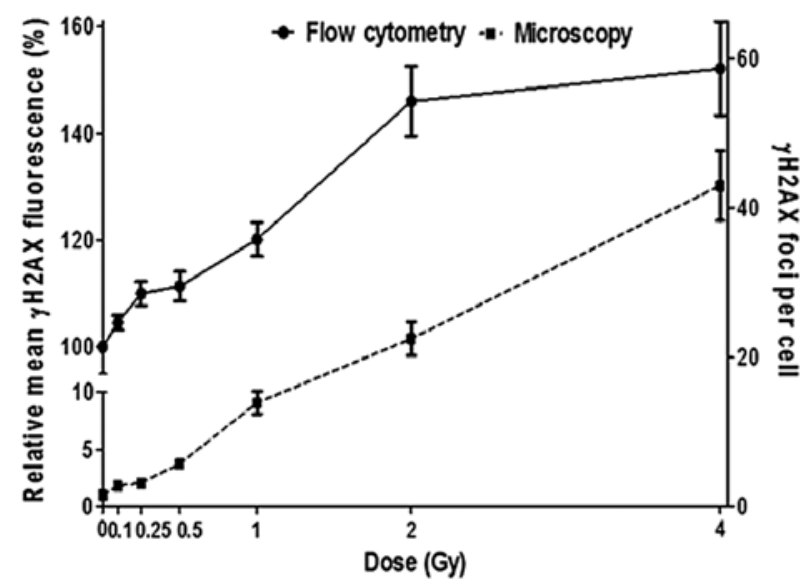

B

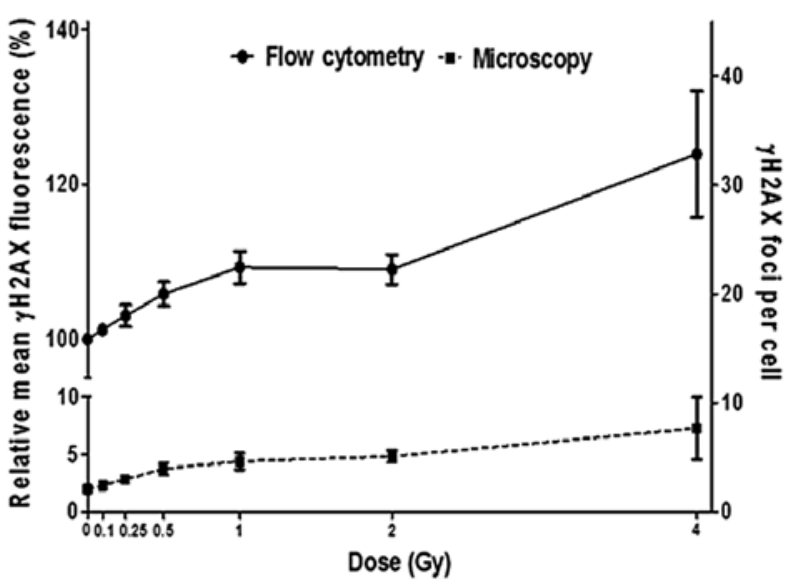

Figure 6. Flow cytometric analysis and microscopic foci analysis for $\gamma \mathrm{H} 2 \mathrm{AX}$ measurement $(0.1,0.25,0.5,1,2$ and 4 Gy) showing the correlation between the 2 methods at (A) $15 \mathrm{~min}$, and (B) $24 \mathrm{~h}$ after irradiation. The experiments were performed in the same 3 donors. The error bars represent \pm SEM.

A

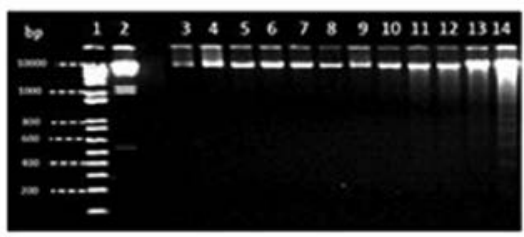

D

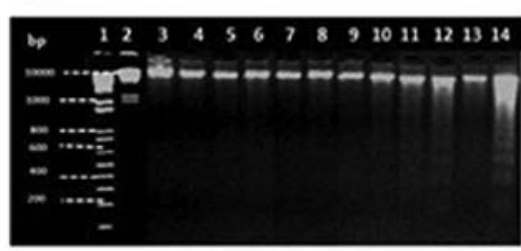

B

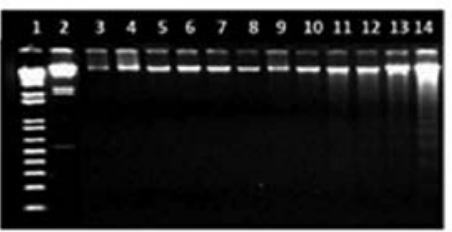

E

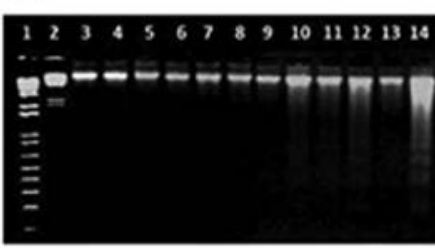

C

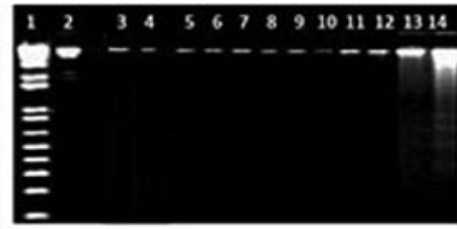

$\mathbf{F}$

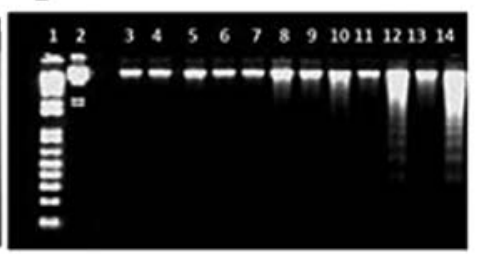

Figure 7. Agarose electrophoresis gel of DNA extracts from PBMCs 0, 4, 24, 48, 72 and $96 \mathrm{~h}$ after irradiation, showing DNA internucleosomal fragmentation (A) at 0.1, (B) 0.25, (C) 0.5, (D) 1, (E) 2 and (F) at 4 Gy. Lane 1, 1 kbp ladder marker; lane 2, 10 kbp ladder marker; lane 3, control at 0 h; lane 4, irradiated sample at $0 \mathrm{~h}$; lane 5, control at $4 \mathrm{~h}$; lane 6, irradiated sample at $4 \mathrm{~h}$; lane 7, control at $24 \mathrm{~h}$; lane 8 , irradiated sample at $24 \mathrm{~h}$; lane 9 , control at $48 \mathrm{~h}$; lane 10 , irradiated sample at $48 \mathrm{~h}$; lane 11, control at $72 \mathrm{~h}$; lane 12, irradiated sample at $72 \mathrm{~h}$; lane 13, control at $96 \mathrm{~h}$; lane 14 , irradiated sample at $96 \mathrm{~h}$.

due to the low initial foci number. Furthermore, even if most radiation-induced DSBs were repaired $24 \mathrm{~h}$ after irradiation, the remaining DSBs were still detectable. The initial number of $\gamma \mathrm{H} 2 \mathrm{AX}$ foci at $0.1,0.25,0.5,1,2$ and 4 Gy were significantly higher at $24 \mathrm{~h}$ compared to controls.

Correlation between flow cytometry and microscopy. The dose-response curves $15 \mathrm{~min}$ and $24 \mathrm{~h}$ after X-irradiation obtained by fluorescence microscopy and flow cytometry are presented in Fig. 6. For both methods and time points, the $\gamma \mathrm{H} 2 \mathrm{AX}$ response increased in a linear dose-dependent way. The slopes were, in flow cytometry and in microscopy, respectively, at $15 \mathrm{~min}, 13.39 \pm 2.095\left(\mathrm{r}^{2}=0.890\right), 10.46 \pm 0.3065$ $\left(r^{2}=0.995\right)$, and at $24 \mathrm{~h}, 5.443 \pm 0.6010\left(r^{2}=0.942\right), 1.289 \pm 0.1502$ $\left(r^{2}=0.936\right)$ (linear regression, $\left.\mathrm{P}<0.005\right)$. Both methods demonstrated that the slopes decreased within $24 \mathrm{~h}$ due to the DSB repair. Fifteen minutes after exposure, we showed a significant increase in $\gamma \mathrm{H} 2 \mathrm{AX}$ levels or $\gamma \mathrm{H} 2 \mathrm{AX}$ foci number per cell in the different dose ranges. The persistence of $\gamma \mathrm{H} 2 \mathrm{AX}$ foci per cell was further investigated for up to $24 \mathrm{~h}$ after radiation exposure (Fig. 6). Residual foci detected $24 \mathrm{~h}$ after irradiation were significantly higher at high doses (respectively, from 0.5 to $4 \mathrm{~Gy}$ in flow cytometry, and $4 \mathrm{~Gy}$ in microscopy, paired t-test, $\mathrm{P}<0.005)$. Therefore, $\gamma \mathrm{H} 2 \mathrm{AX}$ levels detected by use of flow cytometry in irradiated lymphocytes were consistent with the mean number of microscopically detected $\gamma \mathrm{H} 2 \mathrm{AX}$ foci per cell in the same fraction (Fig. 6).

Detection of radiation-induced apoptosis. The nuclease activation of apoptosis can be observed by the formation of a DNA ladder following agarose gel electrophoresis or by labeling of DNA ends (the TUNEL assay) (22), as performed in this study.

DNA ladder. During apoptosis, endonucleases are stimulated and induce genomic DNA fragmentation. These endonucleases are activated by other enzymes called caspases that activate these endonucleases by cutting endonuclease inhibitors. This leads to internucleosomal fragmentation, which leads to the 
Table I. Integrated density values (IDV \pm SEM, \%) based on the DNA ladder electrophoresis performed on PBMCs extracts $48 \mathrm{~h}$ after $\mathrm{X}$-irradiation at $0,0.1,0.25,0.5,1,2$ and $4 \mathrm{~Gy}$.

\begin{tabular}{lccccccc}
\hline & \multicolumn{7}{c}{ IDV (\%), mean \pm SEM } \\
\cline { 2 - 7 } Bands (bp) & Control & 0.1 Gy & 0.25 Gy & 0.5 Gy & 1 Gy & 2 Gy & 4 Gy \\
\hline 180 & $1 \pm 0.11$ & $1 \pm 0.10$ & $1 \pm 0.11$ & $1 \pm 0.10$ & $28 \pm 0.14$ & $30 \pm 0.11$ & $33 \pm 0.12$ \\
360 & $1 \pm 0.12$ & $1 \pm 0.11$ & $1 \pm 0.11$ & $1 \pm 0.10$ & $33 \pm 0.08$ & $32 \pm 0.11$ & $35 \pm 0.13$ \\
540 & $1 \pm 0.09$ & $1 \pm 0.10$ & $1 \pm 0.11$ & $2 \pm 0.10$ & $36 \pm 0.11$ & $35 \pm 0.12$ & $39 \pm 0.12$ \\
720 & $2 \pm 0.12$ & $2 \pm 0.11$ & $2 \pm 0.12$ & $2 \pm 0.12$ & $38 \pm 0.12$ & $39 \pm 0.12$ & $44 \pm 0.09$ \\
900 & $2 \pm 0.09$ & $2 \pm 0.12$ & $2 \pm 0.11$ & $2 \pm 0.12$ & $41 \pm 0.06$ & $43 \pm 0.08$ & $49 \pm 0.08$ \\
\hline
\end{tabular}

Table II. Integrated density values (IDV \pm SEM, \%) based on DNA ladder electrophoresis performed on PBMC extracts $96 \mathrm{~h}$ after $\mathrm{X}$-irradiation at $0,0.1,0.25,0.5,1,2$ and $4 \mathrm{~Gy}$.

\begin{tabular}{llllllll}
\hline & \multicolumn{7}{c}{ IDV (\%), mean \pm SEM } \\
\cline { 2 - 8 } Bands (bp) & Control & 0.1 Gy & 0.25 Gy & 0.5 Gy & 1 Gy & 2 Gy & 4 Gy \\
\hline 180 & $19 \pm 0.11$ & $23 \pm 0.14$ & $26 \pm 0.13$ & $29 \pm 0.11$ & $34 \pm 0.12$ & $35 \pm 0.12$ & $46 \pm 0.13$ \\
360 & $22 \pm 0.12$ & $32 \pm 0.08$ & $33 \pm 0.1$ & $36 \pm 0.11$ & $42 \pm 0.13$ & $44 \pm 0.1$ & $56 \pm 0.11$ \\
540 & $30 \pm 0.09$ & $38 \pm 0.11$ & $39 \pm 0.11$ & $41 \pm 0.12$ & $46 \pm 0.12$ & $48 \pm 0.13$ & $64 \pm 0.09$ \\
720 & $36 \pm 0.12$ & $41 \pm 0.12$ & $44 \pm 0.09$ & $46 \pm 0.12$ & $48 \pm 0.09$ & $49 \pm 0.1$ & $70 \pm 0.1$ \\
900 & $39 \pm 0.09$ & $49 \pm 0.06$ & $49 \pm 0.1$ & $50 \pm 0.08$ & $55 \pm 0.08$ & $55 \pm 0.1$ & $71 \pm 0.11$ \\
\hline
\end{tabular}

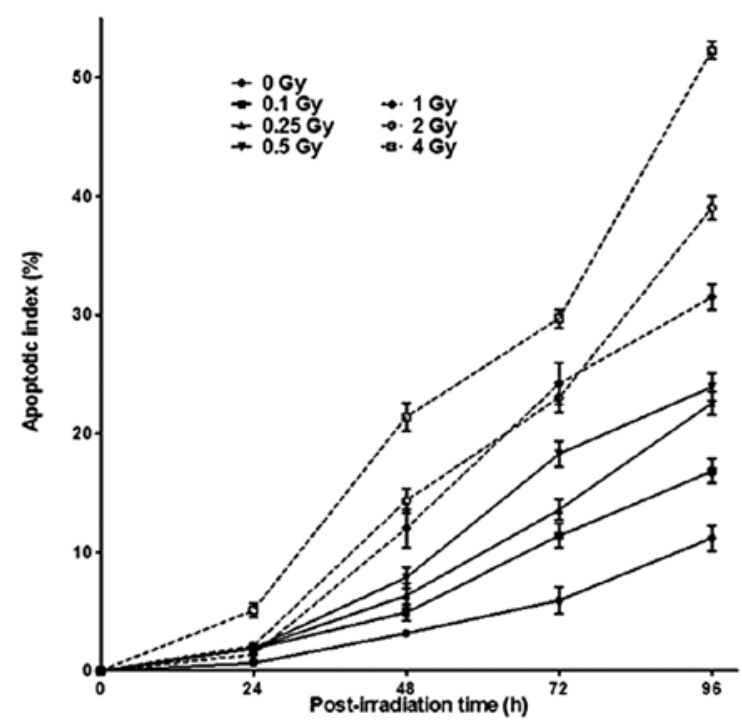

Figure 8. Spontaneous and radiation-induced apoptosis in PBMCs $0,24,48$, 72 and $96 \mathrm{~h}$ after irradiation at low, moderate and high doses $(0.1,0.25,0.5$, 1,2 and $4 \mathrm{~Gy}$ ). The apoptotic index (AI) was used to represent radiationinduced levels of apoptosis at different time points after X-irradiation. The error bars represent $\pm \operatorname{SEM}(n=3)$.

formation of mono- (180 bp) and oligonucleosomes. This process can be visualized through the appearance of a 'DNA ladder' by a gel electrophoresis technique. Radiation-induced apoptosis in PBMCs was analyzed for the presence of the DNA ladder at different time points $(0,24,48,72$ and $96 \mathrm{~h})$ after low and high dose X-irradiation $(0.1,0.25,0.5,1,2$ and
4 Gy) (Fig. 7). In addition, although DNA ladder gel electrophoresis is a semi-quantitative method for DNA fragmentation in apoptosis, the apoptotic fragmentation was evaluated with the IDV (Tables I and II). We showed that the apoptotic DNA fragmentation increased significantly depending on the dose (paired t-test, $\mathrm{P}<0.005$ ). Indeed, after irradiation with low and moderate doses (0.1, 0.25 and $0.5 \mathrm{~Gy}$ ), an increase in DNA fragmentation was observed only after $96 \mathrm{~h}$ (Table I). At high doses (1, 2 and $4 \mathrm{~Gy})$, an increase in DNA fragmentation was clearly observed already from $48 \mathrm{~h}$ onwards after irradiation. We also showed that at high doses (1,2 and 4 Gy) there was a significant time-dependent increase in DNA fragmentation between $48 \mathrm{~h}$ (a beginning of genomic DNA fragmentation was observed) and $96 \mathrm{~h}$ (Tables I and II). At 72 and 96 h, apoptotic DNA fragmentation was clearly observed and the band intensity increased significantly after irradiation $(\mathrm{P}<0.005)$.

TUNEL assay. Levels of spontaneous or radiation-induced apoptosis in PBMCs samples are presented in Fig. 8 after different incubation times $(0,24,48,72$ and $96 \mathrm{~h})$ with different doses of X-rays $(0,0.1,0.25,0.5,1,2$ and $4 \mathrm{~Gy})$. The apoptotic index was used to represent radiation-induced levels of apoptosis. Representative images of PBMCs analysed by a TUNEL assay are illustrated in Fig. 9.

Using the TUNEL assay, DNA fragmentation was detected at the early time points (starting from $24 \mathrm{~h}$ in all dose ranges, Fig. 8). Indeed, early in the process of apoptosis, DNA cleavage generates high molecular weight (HMW) fragments which can be detected by the TUNEL assay. This is followed by a pronounced DNA breakdown into low molecular weight (LMW) fragments, detected as a 'DNA ladder' by 
A

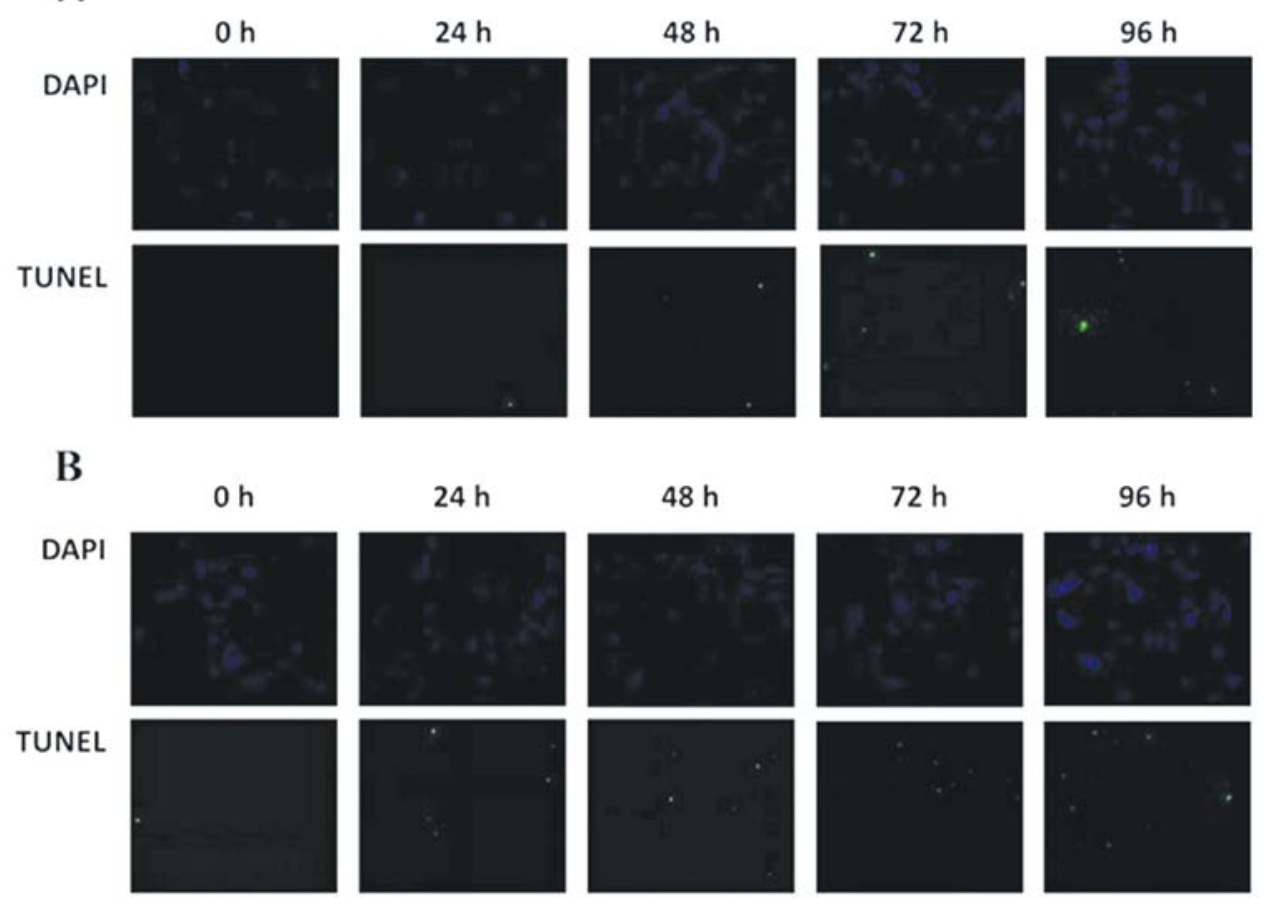

Figure 9. A gallery of images of PBMCs, using the TUNEL assay analyzed by microscopy, illustrating the DNA fragmentation at different time points $(0,24$, 48,72 and $96 \mathrm{~h}$ ) (A) in controls or (B) in irradiated samples at $0.1 \mathrm{~Gy}$ (nuclei were counterstained with DAPI).

conventional agarose gel electrophoresis (mono-, 180-bp and oligonucleosomes). The TUNEL assay is considered as a more sensitive method (from $24 \mathrm{~h}$ in all dose ranges, Fig. 8) for detection of apoptosis compared to DNA ladder gel electrophoresis. By DNA ladder, the apoptotic DNA fragmentation was detected respectively, starting at $48 \mathrm{~h}$ at high doses $(1,2$, and $4 \mathrm{~Gy}$ ) and at only $96 \mathrm{~h}$ after low/moderate doses of X-rays $(0.1,0.25,0.5 \mathrm{~Gy})$.

Using the TUNEL assay, we observed spontaneous apoptosis in non-irradiated controls, as well as radiation-induced apoptosis after 24 until $96 \mathrm{~h}$ post-irradiation. In this time course, the level of spontaneous apoptosis was significantly lower compared to radiation-induced apoptosis.

The results obtained from the TUNEL assay showed a time- and dose-dependency in radiation-induced apoptosis (two-way ANOVA, $\mathrm{P}<0.005$ ).

Regression analysis $(\mathrm{P}<0.005)$ was used and showed a timelinear dependency, slopes being at $0.1,0.25,0.5,1,2$ and $4 \mathrm{~Gy}$, respectively, $0.18 \pm 0.022\left(\mathrm{r}^{2}=0.935\right), 0.24 \pm 0.034\left(\mathrm{r}^{2}=0.939\right)$, $0.27 \pm 0.033\left(r^{2}=0.955\right), 0.36 \pm 0.043\left(r^{2}=0.957\right), 0.41 \pm 0.054$ $\left(r^{2}=0.950\right), 0.53 \pm 0.067,\left(r^{2}=0.955\right)$. These data showed a significant increase of the slope in the apoptotic response from 0.1 until 4 Gy of X-ray irradiation (with a maximum apoptotic index at $96 \mathrm{~h}$ ).

\section{Discussion}

Kinetics of DSB foci formation using microscopy. One of the earliest stages in the cellular response to DSBs is the phosphorylation of the histone variant H2AX. Discrete nuclear foci at sites of DSBs can be visualized by immunofluorescence microscopy (6). In our in vitro experiments, we found a linear dose-dependent response in $\gamma \mathrm{H} 2 \mathrm{AX}$ foci formation in irradi- ated PBMCs. The number of $\gamma \mathrm{H} 2 \mathrm{AX}$ foci linearly increased with the radiation dose studied (0-4 Gy). In PBMCs fixed $15 \mathrm{~min}$ after exposure to ionizing radiation, we measured on average $2.8( \pm 0.47)$ foci/cell/Gy at $0.1 \mathrm{~Gy}$ compared to 3 foci/cell estimated and reported in irradiated whole blood cells and T-lymphocytes at $0.1 \mathrm{~Gy}$ (23). These results show a general agreement among different investigators. Similarly, we measured on average $5.7( \pm 0.20)$ and $13.9( \pm 1.52)$ foci/cell at respective doses of 0.5 and 1 Gy while Rothkamm et al (24) reported in irradiated PBMCs 5.5 and 11.5 foci/cell for the same dose. The estimation of $13.9( \pm 1.52)$ foci/cell after $1 \mathrm{~Gy}$ irradiation is a rather low number compared to estimates usually seen with cells in culture such as lymphoblastoid cells $(25,26)$, human fibroblast cells (27) or human breast cancer cells (28). The lower number of $\gamma \mathrm{H} 2 \mathrm{AX}$ foci in PBMCs could have several explanations. First, G0 cells possess less genetic material than dividing cells in culture. In fact, a previous study (26) showed that twice as many $\gamma \mathrm{H} 2 \mathrm{AX}$ foci are observed in metaphase cells relative to G1 cells at any given dose. Second, it is known that higher order chromatin structure can also influence the distribution of DNA DSBs. For example, in higher eukaryotic cells, some part of chromatin is condensed to make heterochromatin which is refractory to $\gamma \mathrm{H} 2 \mathrm{AX}$ foci formation (29). The differences observed could be due to various technical issues and/or variations in foci counting by different investigators.

Furthermore, we showed a time-dependent induction and disappearance in $\gamma \mathrm{H} 2 \mathrm{AX}$ focus formation. The formation of $\gamma \mathrm{H} 2 \mathrm{AX}$ foci at the DNA damage site is fast, with $\gamma \mathrm{H} 2 \mathrm{AX}$ foci forming within 3-15 min and reaching a maximum level followed by a dephosphorylation over the next few hours $(6,9,30-33)$. In vitro studies on irradiated human lymphocytes found a maximum level of $\gamma \mathrm{H} 2 \mathrm{AX}$ foci within $15-30 \mathrm{~min}$ 
(34-36), in agreement with our results. For cell cultures, $30 \mathrm{~min}$ is found to be the optimum time for determining the maximum yield of $\mathrm{H} 2 \mathrm{AX}$ foci for various cell types such as human lung embryonic fibroblasts, human fetal lung fibroblasts and human breast tumor cell line $(6,31,37)$. In the time-course, we showed that DNA DSBs are repaired with biphasic kinetics, a rapid phase lasting several hours (a rapid decline in $\gamma \mathrm{H} 2 \mathrm{AX}$ foci until $4 \mathrm{~h}$ ) followed by a slower phase (a slower loss of $\gamma \mathrm{H} 2 \mathrm{AX}$ foci until $24 \mathrm{~h}$ ). This DSB repair kinetic pattern has been reported previously by Sedelnikova et al (33), in human peripheral blood lymphocytes and in human fibroblasts after $\gamma$-irradiation. These kinetics can be explained by the fact that ionizing radiation induces DSBs that can vary from simple to more complex structures $(38,39)$. For low-linear energy transfer (LET) radiation, it has been estimated that $20-40 \%$ of the initial damage is complex (38-40). We can hypothesize that this non-uniformity in DNA damage would result in a delay in the repair of the more complex DSBs. Multiple high number of adjacent DSBs could inhibit the attachment of repair proteins to other nearby DSBs, and this possibility increases with the ionization density or LET of the radiation (32). The slow component of DSB repair (after $4 \mathrm{~h}$ ) would be consistent with the accumulation of repair factors in the foci. Indeed, the time course of localization of various proteins in the foci indicates that they are assembled in a defined sequence. Mediator of DNA damage checkpoint protein 1 (MDC1) and p53 binding protein 1 (53BP1) colocalize very rapidly 5-15 min after irradiation $(41,42)$. MDC1 plays an important role in assembling other repair and checkpoint proteins (43). A previous study (44) indicates that the interacting MDC1 and $\gamma \mathrm{H} 2 \mathrm{AX}$ molecules form an 'affinity platform' on which other proteins are assembled and retained $(12,42)$. As discussed previously (45), modification of the H2AX molecules may be important to alter the local chromatin structure in the surrounding of a DSB thereby increasing the accessibility of DNA to various repair factors.

In the present study, the immunofluorescence-based assay that allows the visualization of discrete nuclear foci formed as a result of $\mathrm{H} 2 \mathrm{AX}$ phosphorylation was shown to be a sensitive and reliable method for detecting radiation-induced DSBs. Our results indicate that $\gamma \mathrm{H} 2 \mathrm{AX}$ foci may be a quantitative biomarker of human radiation exposure. Given its specificity and sensitivity, analysis of $\gamma \mathrm{H} 2 \mathrm{AX}$ foci can be also a useful method of investigating DNA damage and repair efficiency.

Linear dose-response in radiation-induced $H 2 A X$ phosphorylation using flow cytometry. Currently, the $\gamma \mathrm{H} 2 \mathrm{AX}$ focus formation is being used as a DNA damage marker, specifically for DSBs induced by exposure to various genotoxic agents, such as ionizing radiation (6). In this study, we thought that by measuring cellular levels of $\gamma \mathrm{H} 2 \mathrm{AX}$ by high-throughput flow cytometry will allow straightforward assessments of radiation-induced DNA damage and ability to repair such DNA damage.

Using flow cytometric analysis, the dose response of $\gamma \mathrm{H} 2 \mathrm{AX}$ induction in lymphocytes was found to be linear in the studied dose range (0-4 Gy). These results are similar to the results we obtained by $\gamma \mathrm{H} 2 \mathrm{AX}$ foci formation analyzed by immufluorescence microscopy. This is in agreement with previous studies using mainly microscopy that showed a linear dose response up to $40 \mathrm{~Gy}$ with a gradual saturation above this dose $(5,6,8,9,46-49)$. By examining the time course of the $\gamma \mathrm{H} 2 \mathrm{AX}$ response, our results showed that the intensity of the $\gamma \mathrm{H} 2 \mathrm{AX}$ signal increased rapidly up to $1 \mathrm{~h}$. A maximum response was observed between 1 and $2 \mathrm{~h}$ and was maintained for approximately $1 \mathrm{~h}$ (as seen at 0.25 and $4 \mathrm{~Gy}$ ) before starting to decrease towards background levels. This time point of maximum response is different than in microscopy: the $\gamma$-H2AX quantification in flow cytometry is based on measuring the total fluorescence intensity for each cell while fluorescence microscopy imaging is depend on $\gamma$-H2AX foci scoring. By $24 \mathrm{~h}$, the $\gamma \mathrm{H} 2 \mathrm{AX}$ signal had returned to background levels at all doses except at 4 Gy due to DSB repair. Similar results have been reported in other studies, with H2AX phosphorylation being detected as soon as 1-3 min post irradiation and the maximum response at 9-30 $\min (5,6,31,48,49)$. In agreement with our study, previous studies using human lymphocytes found maximum $\gamma \mathrm{H} 2 \mathrm{AX}$ induction at $1-2 \mathrm{~h}$ postexposure (50). All of these previous studies support the idea that the exact form of time response depends on the dose and the type of cells, although irradiation conditions (temperature) (51) could also have an effect on the response time $(8,9,48,49)$. This supports previous findings that radioresistant cultures dephosphorylate faster than radiosensitive ones $(8,9,49,52)$. In our study, the half-time of $\mathrm{H} 2 \mathrm{AX}$ dephosphorylation was estimated from the time response curves and found to be 2-4 $\mathrm{h}$ which is in agreement with a previous study $(3 \mathrm{~h}$, in human peripheral blood lymphocytes) (30).

This flow cytometry assay has been used to characterize the radiation response of lymphocytes. Flow cytometry is a rapid tool for measuring the induction of DNA DSB damage, although the total signal measured does not provide the same level of sensitivity as counting the number and/or size of the $\gamma \mathrm{H} 2 \mathrm{AX}$ foci by microscopy. Furthermore, the ability of flow cytometers to analyze thousands of lymphocytes every second allows the reduction of processing times from days to hours, working with multiple samples simultaneously. In contrast, the immunofluorescence microscopy-based assay is time-consuming, operator-dependent and is not easily scalable for high throughput assay development. In this study, results showed a linear response with the dose in $\gamma \mathrm{H} 2 \mathrm{AX}$ phosphorylation by flow cytometry. These findings reinforce the idea that $\gamma \mathrm{H} 2 \mathrm{AX}$ biodosimetry can be a robust tool for estimating radiation exposure. This flow cytometry based method can be used on a large scale to assess its potential as rapid, high throughput biodosimeter for mass casualty situations.

Residual foci and radiation-induced apoptosis. The majority of DSBs are repaired within a few hours post-irradiation. Localization of DSB in specific areas of chromatin or complexity of DSB may be important constraints for the efficiency of the DSB repair. In this context, DSB present in residual foci (representing unrepaired DNA damage) may hypothetically represent a sufficient event for triggering apoptosis.

Induction of apoptosis in human lymphocytes and subpopulations of human lymphocytes (53) by ionizing radiation has been observed both in vitro $(54,55)$ and in vivo $(56)$. DNA damage results in a coordinated network of signal transduction pathways involved in cell cycle arrest, apoptosis, stress response and activation of the DNA repair processes (57). In 
our study, differences were observed in the ability of PBMCs to repair DSBs induced by X-rays in the studied dose range. At $24 \mathrm{~h}$ after irradiation, the lower numbers of DSBs induced by lower doses ( 0.1 and $0.25 \mathrm{~Gy}$ ) of radiation were repaired more easily than the large number of DSBs induced by the higher doses $(0.5,1,2$ and $4 \mathrm{~Gy})$. According to the data obtained, after the higher doses a large number of unrepaired ionizing radiation-induced foci persisted in cells $24 \mathrm{~h}$ after irradiation. However, so far, no data are available to correlate residual DSB with radiation-induced apoptosis in lymphocytes. DSB in residual foci may represent a sufficient event for triggering apoptosis. Localization of DSB in specific areas of chromatin or complexity of DSB may be important constraints for the efficiency of the DSB repair. In particular, 2 or more DSBs might be involved in the formation of residual foci. Such breaks may take a longer time to be repaired and could result in triggering the apoptotic signal transduction because of the failure to repair DSBs.

Other radiation-induced foci may contain only 1 , or less complex DSB, which may be subjected to faster repair and therefore do not signal for apoptosis. Radiation-induced unrepaired DSBs may be responsible for the induction of apoptosis. In our study, we showed by DNA ladder gel electrophoresis that the highest level of apoptotic fragmentation was observed after $96 \mathrm{~h}$ at low and moderate doses $(0.1,0.25$, $0.5 \mathrm{~Gy})$ and after $48 \mathrm{~h}$ at high doses (1, 2 and $4 \mathrm{~Gy})$. It should be noted that the kinetics of apoptosis induced by irradiation in vivo may be different from that found after irradiation of cells in vitro. Apoptosis in vivo is already observed after 3-12 h following irradiation (58-61), while apoptosis in vitro requires $24-48 \mathrm{~h}$ to reach maximal levels $(54,62,63)$. The TUNEL assay results revealed that the frequency of apoptotic cells progressively increased in a dose- and time-dependent manner. The DNA cleavage into large fragments detected by the sensitive TUNEL assay is an early event observed in the apoptotic cascade before the typical endonuclease cleavage into 180 to 200 bp can be detected as a 'DNA ladder' (64). This DNA breakage is exactly what we observed in our experiments. DNA damage monitoring and signaling processes are responsible for cell cycle checkpoint control and failure of these checkpoints leads to cell death (65). The key players in DNA damage recognition and signaling are p53, DNA-PK, poly(ADP ribose) polymerase (PARP), and ATM. PARP, DNA-PK and ATM act upstream of p53. Previous studies (66-68) have suggested that DNA-PK plays a pivotal role in apoptosis. The cell cycle arrest induced by DNA damage may result in DNA repair and therefore in removal of the cell cycle blockade, when the repair is completed. If, however, cells undergo apoptosis, their capacity to repair damaged DNA is suppressed as enzymes responsible for DNA damage repair are cleaved by proteases (67). In apoptosis, nuclear chromatin undergoes condensation, during which a calcium-dependent endonuclease is activated, resulting in cleavage of nuclear DNA into fragments of 180-200 base pairs in length or multiples of them $(69,70)$. Induction of apoptosis in human lymphocytes and subpopulations of human lymphocytes (53) by ionizing radiation has been observed both in vitro $(54,55)$ and in vivo (56). It is important to note that some cell types are more sensitive to undergo apoptosis than others and that the signaling pathways employed by these different cell types to induce apoptosis may vary accordingly. Radiation-induced apoptotic signaling can be initiated in different cellular compartments, including the nucleus, cytosolic elements and plasma membrane.

In this study, we showed the cytotoxic effects of radiation in irradiated PBMCs from healthy donors by measurement of apoptosis. These adverse biological effects induced by radiation in terms of cytotoxicity is important for acute effects because apoptosis is a rapid process that can dramatically reduce cell number. Furthermore, a dose- and time-dependency of apoptotic fragmentation in irradiated cells can be used as a marker to predict unusual risk of side effects, to diagnose a cytotoxicity as radiation-related, and in the case of bioterror, allow for tissue-specific biodosimetry.

In conclusion, $\mathrm{H} 2 \mathrm{AX}$ has been widely used by many researchers as a tool to measure radiation-induced DNA damage. In the present study, a linear dose-dependency of $\gamma \mathrm{H} 2 \mathrm{AX}$ phosphorylation was observed in $\gamma \mathrm{H} 2 \mathrm{AX}$ foci in PBMCs detected by microscopy as well as measured by flow cytometry from 15 min until $24 \mathrm{~h}$ following irradiation. These findings showed that $\gamma \mathrm{H} 2 \mathrm{AX}$ itself is a good candidate for biodosimetry. In addition, our results show the exciting opportunity to employ $\gamma \mathrm{H} 2 \mathrm{AX}$ foci formation for monitoring human exposure to low doses ( $<100 \mathrm{mGy})$ of ionizing radiation. Furthermore, PBMCs are easily obtained with minimal invasion, have very low levels of background $\gamma \mathrm{H} 2 \mathrm{AX}$ expression validating its use as a tissue sample for damage detection following radiation exposure $(24,48,49)$. The use of $\gamma \mathrm{H} 2 \mathrm{AX}$ as a high throughput biodosimeter in flow cytometry would be useful for a day post-exposure applications, like large-scale radiological events or radiation therapy.

Of the different types of radiation-induced deleterious cellular lesions, DSBs have been considered to be the most relevant for cytotoxic effects of radiation and induction of apoptosis $(71,72)$. In our study, we explored the association between radiation-induced DNA damage, estimated by the number of DSB induced in the studied radiation dose (0-4 Gy) and the radiation-induced apoptosis rates. Radiation-induced apoptosis could be a biodosimetric indicator in the case of radiation exposure.

After $24 \mathrm{~h}$, residual $\gamma \mathrm{H} 2 \mathrm{AX}$ foci were still detectable in irradiated cells, and apoptotic fragmentation was observed from 24 until $96 \mathrm{~h}$ in a dose-dependent manner. Modulation of the apoptotic response, which might be explained by the inefficiency or misrepair of the DSBs, can result in transduction pathways enhancing the cytotoxic effect of radiation. These signal transduction pathways include the radiation-induced apoptosis. Which of these signaling systems is instrumental for apoptosis induction is still unknown and may depend on the cell system, the type of stimulus and the input of other apoptosis-regulating factors.

\section{Acknowledgements}

The research was financially supported by the Belgian Science Policy (BELSPO contract BL/52/C43) and by the European Space Agency (ESA)/Belspo/Prodex grant (MOSAIC C90-380, MOSAIC2 42-000-90-380). The authors express their sincere gratitude to the volunteers who donated the blood samples, allowing this study. 


\section{References}

1. Bakkenist CJ and Kastan MB: DNA damage activates ATM through intermolecular autophosphorylation and dimer dissociation. Nature 421: 499-506, 2003.

2. Bartek J and Lukas J: DNA repair: damage alert. Nature 421: 486-488, 2003.

3. Hoeijmakers JH: Genome maintenance mechanisms for preventing cancer. Nature 411: 366-374, 2001.

4. Shiloh Y: ATM and related protein kinases: safeguarding genome integrity. Nat Rev Cancer 3: 155-168, 2003

5. Rogakou EP, Pilch DR, Orr AH, Ivanova VS and Bonner WM: DNA double-stranded breaks induce histone $\mathrm{H} 2 \mathrm{AX}$ phosphorylation on serine 139. J Biol Chem 273: 5858-5868, 1998.

6. Rogakou EP, Boon C, Redon C and Bonner WM: Megabase chromatin domains involved in DNA double-strand breaks in vivo. J Cell Biol 146: 905-916, 1999.

7. Kuerbitz SJ, Plunkett BS, Walsh WV and Kastan MB: Wild-type p53 is a cell cycle checkpoint determinant following irradiation. Proc Natl Acad Sci USA 89: 7491-7495, 1992.

8. MacPhail SH, Banath JP, Yu TY, Chu EH, Lambur H and Olive PL: Expression of phosphorylated histone H2AX in cultured cell lines following exposure to X-rays. Int J Radiat Biol 79: 351-358, 2003.

9. Banath JP, Macphail SH and Olive PL: Radiation sensitivity, H2AX phosphorylation, and kinetics of repair of DNA strand breaks in irradiated cervical cancer cell lines. Cancer Res 64: 7144-7149, 2004.

10. Fernandez-Capetillo O, Lee A, Nussenzweig $M$ and Nussenzweig A: H2AX: the histone guardian of the genome. DNA Repair (Amst) 3: 959-967, 2004

11. Lukas C, Falck J, Bartkova J, Bartek J and Lukas J: Distinct spatiotemporal dynamics of mammalian checkpoint regulators induced by DNA damage. Nat Cell Biol 5: 255-260, 2003.

12. Lukas C, Melander F, Stucki M, et al: Mdc1 couples DNA double-strand break recognition by Nbs1 with its H2AXdependent chromatin retention. EMBO J 23: 2674-2683, 2004

13. Mailand N, Bekker-Jensen S, Faustrup H, et al: RNF8 ubiquitylates histones at DNA double-strand breaks and promotes assembly of repair proteins. Cell 131: 887-900, 2007.

14. Bekker-Jensen S, Lukas C, Kitagawa R, et al: Spatial organization of the mammalian genome surveillance machinery in response to DNA strand breaks. J Cell Biol 173: 195-206, 2006.

15. Su TT: Cellular responses to DNA damage: one signal, multiple choices. Annu Rev Genet 40: 187-208, 2006

16. Story MD, Voehringer DW, Malone CG, Hobbs ML and Meyn RE: Radiation-induced apoptosis in sensitive and resistant cells isolated from a mouse lymphoma. Int J Radiat Biol 66: 659-668, 1994.

17. Bennett CB, Lewis AL, Baldwin KK and Resnick MA: Lethality induced by a single site-specific double-strand break in a dispensable yeast plasmid. Proc Natl Acad Sci USA 90: 5613-5617, 1993

18. Huang X, Okafuji M, Traganos F, Luther E, Holden E and Darzynkiewicz Z: Assessment of histone H2AX phosphorylation induced by DNA topoisomerase I and II inhibitors topotecan and mitoxantrone and by the DNA cross-linking agent cisplatin. Cytometry A 58: 99-110, 2004.

19. De Vos WH, Van Neste L, Dieriks B, Joss GH and Van Oostveldt P. High content image cytometry in the context of subnuclear organization. Cytometry A 77: 64-75, 2010.

20. Schnizlein-Bick CT, Mandy FF, O'Gorman MR, et al: Use of CD45 gating in three and four-color flow cytometric immunophenotyping: guideline from the National Institute of Allergy and Infectious Diseases, Division of AIDS. Cytometry 50: 46-52, 2002

21. Glencross D, Scott LE, Jani IV, Barnett D and Janossy G CD45-assisted PanLeucogating for accurate, cost-effective dualplatform CD4+ T-cell enumeration. Cytometry 50: 69-77, 2002.

22. Darzynkiewicz Z and Traganos F: Measurement of apoptosis. Adv Biochem Eng Biotechnol 62: 33-73, 1998.

23. Beels L, Werbrouck J and Thierens H: Dose response and repair kinetics of gamma-H2AX foci induced by in vitro irradiation of whole blood and T-lymphocytes with $\mathrm{X}$ - and gamma-radiation. Int J Radiat Biol 86: 760-768, 2010.

24. Rothkamm K, Balroop S, Shekhdar J, Fernie P and Goh V: Leukocyte DNA damage after multi-detector row CT: a quantitative biomarker of low-level radiation exposure. Radiology 242 : 244-251, 2007.

25. Kato TA, Nagasawa H, Weil MM, Little JB and Bedford JS Levels of gamma-H2AX Foci after low-dose-rate irradiation reveal a DNA DSB rejoining defect in cells from human ATM heterozygotes in two at families and in another apparently normal individual. Radiat Res 166: 443-453, 2006.
26. Kato TA, Okayasu R and Bedford JS: Comparison of the induction and disappearance of DNA double strand breaks and gamma-H2AX foci after irradiation of chromosomes in G1-phase or in condensed metaphase cells. Mutat Res 639: 108-112, 2008

27. Leatherbarrow EL, Harper JV, Cucinotta FA and O'Neill P: Induction and quantification of gamma-H2AX foci following low and high LET-irradiation. Int J Radiat Biol 82: 111-118, 2006.

28. Yasui LS: GammaH2AX foci induced by gamma rays and ${ }^{125}$ IdU decay. Int J Radiat Biol 80: 895-903, 2004.

29. Goodarzi AA, Noon AT, Deckbar D, et al: ATM signaling facilitates repair of DNA double-strand breaks associated with heterochromatin. Mol Cell 31: 167-177, 2008.

30. Olive PL and Banath JP: Phosphorylation of histone H2AX as a measure of radiosensitivity. Int $\mathrm{J}$ Radiat Oncol Biol Phys 58: 331-335, 2004

31. Antonelli F, Belli M, Cuttone G, et al: Induction and repair of DNA double-strand breaks in human cells: dephosphorylation of histone H2AX and its inhibition by calyculin A. Radiat Res 164: 514-517, 2005

32. Cucinotta FA, Pluth JM, Anderson JA, Harper JV and O'Neill P: Biochemical kinetics model of DSB repair and induction of gamma-H2AX foci by non-homologous end joining. Radiat Res 169: 214-222, 2008.

33. Sedelnikova OA, Horikawa I, Redon C, et al: Delayed kinetics of DNA double-strand break processing in normal and pathological aging. Aging Cell 7: 89-100, 2008.

34. Sak A and Stuschke M: Use of gammaH2AX and other biomarkers of double-strand breaks during radiotherapy. Semin Radiat Oncol 20: 223-231, 2010.

35. Redon CE, Dickey JS, Bonner WM and Sedelnikova OA: Gamma$\mathrm{H} 2 \mathrm{AX}$ as a biomarker of DNA damage induced by ionizing radiation in human peripheral blood lymphocytes and artificial skin. Adv Space Res 43: 1171-1178, 2009.

36. Roch-Lefevre S, Mandina T, Voisin P, et al: Quantification of gamma-H2AX foci in human lymphocytes: a method for biological dosimetry after ionizing radiation exposure. Radiat Res 174: 185-194, 2010

37. Paull TT, Rogakou EP, Yamazaki V, Kirchgessner CU, Gellert M and Bonner WM: A critical role for histone $\mathrm{H} 2 \mathrm{AX}$ in recruitment of repair factors to nuclear foci after DNA damage. Curr Biol 10: 886-895, 2000.

38. Goodhead DT: Initial events in the cellular effects of ionizing radiations: clustered damage in DNA. Int J Radiat Biol 65: 7-17, 1994.

39. NikjooH,O'Neill P, Wilson WEand Goodhead DT: Computational approach for determining the spectrum of DNA damage induced by ionizing radiation. Radiat Res 156: 577-583, 2001

40. Gulston M,Fulford J, Jenner T, de Lara C and O'Neill P: Clustered DNA damage induced by gamma radiation in human fibroblasts (HF19), hamster (V79-4) cells and plasmid DNA is revealed as Fpg and Nth sensitive sites. Nucleic Acids Res 30: 3464-3472, 2002.

41. Schultz LB, Chehab NH, Malikzay A and Halazonetis TD: p53 binding protein 1 (53BP1) is an early participant in the cellular response to DNA double-strand breaks. J Cell Biol 151: 1381-1390, 2000

42. Stucki M, Clapperton JA, Mohammad D, Yaffe MB, Smerdon SJ and Jackson SP: MDC1 directly binds phosphorylated histone $\mathrm{H} 2 \mathrm{AX}$ to regulate cellular responses to DNA double-strand breaks. Cell 123: 1213-1226, 2005.

43. $\mathrm{Xu} X$ and Stern DF: NFBD1/MDC1 regulates ionizing radiation-induced focus formation by DNA checkpoint signaling and repair factors. FASEB J 17: 1842-1848, 2003.

44. Stucki M and Jackson SP: gammaH2AX and MDC1: anchoring the DNA-damage-response machinery to broken chromosomes. DNA Repair (Amst) 5: 534-543, 2006.

45. Paull TT and Gellert M: The 3 ' to 5 ' exonuclease activity of Mre11 facilitates repair of DNA double-strand breaks. Mol Cell 1: 969-979, 1998.

46. Bonner WM: Low-dose radiation: thresholds, bystander effects, and adaptive responses. Proc Natl Acad Sci USA 100: 4973-4975, 2003.

47. Pilch DR, Sedelnikova OA, Redon C, Celeste A, Nussenzweig A and Bonner WM: Characteristics of gamma-H2AX foci at DNA double-strand breaks sites. Biochem Cell Biol 81: 123-129, 2003.

48. Rothkamm K and Lobrich M: Evidence for a lack of DNA double-strand break repair in human cells exposed to very low x-ray doses. Proc Natl Acad Sci USA 100: 5057-5062, 2003. 
49. Lobrich M, Rief N, Kuhne M, et al: In vivo formation and repair of DNA double-strand breaks after computed tomography examinations. Proc Natl Acad Sci USA 102: 8984-8989, 2005.

50. Hamasaki K, Imai K, Nakachi K, Takahashi N, Komada Y and Kusunoki Y: Short-term culture and gammaH2AX flow cytometry determine differences in individual radiosensitivity in human peripheral T lymphocytes. Environ Mol Mutagen 48: $38-47,2007$.

51. Hamada N, Schettino G, Kashino G, et al: Histone H2AX phosphorylation in normal human cells irradiated with focused ultrasoft $\mathrm{X}$ rays: evidence for chromatin movement during repair. Radiat Res 166: 31-38, 2006.

52. Taneja N, Davis M, Choy JS, et al: Histone H2AX phosphorylation as a predictor of radiosensitivity and target for radiotherapy. J Biol Chem 279: 2273-2280, 2004

53. Ozsahin M, Ozsahin H, Shi Y, Larsson B, Wurgler FE and Crompton NE: Rapid assay of intrinsic radiosensitivity based on apoptosis in human CD4 and CD8 T-lymphocytes. Int J Radiat Oncol Biol Phys 38: 429-440, 1997.

54. Boreham DR, Gale KL, Maves SR, Walker JA and Morrison DP: Radiation-induced apoptosis in human lymphocytes: potential as a biological dosimeter. Health Phys 71: 685-691, 1996.

55. Hertveldt K, Philippe J, Thierens H, Cornelissen M, Vral A and De Ridder L: Flow cytometry as a quantitative and sensitive method to evaluate low dose radiation induced apoptosis in vitro in human peripheral blood lymphocytes. Int J Radiat Biol 71: 429-433, 1997.

56. Delic J, Magdelenat H, Barbaroux C, et al: In vivo induction of apoptosis in human lymphocytes by therapeutic fractionated total body irradiation. Br J Radiol 68: 997-1003, 1995.

57. Kanaar R, Hoeijmakers JH and van Gent DC: Molecular mechanisms of DNA double strand break repair. Trends Cell Biol 8: 483-489, 1998.

58. Ijiri K and Potten CS: The circadian rhythm for the number and sensitivity of radiation-induced apoptosis in the crypts of mouse small intestine. Int J Radiat Biol 58: 165-175, 1990.

59. Stephens LC, Ang KK, Schultheiss TE, Milas L and Meyn RE: Apoptosis in irradiated murine tumors. Radiat Res 127: 308-316, 1991

60. Inouye M, Tamaru M and Kameyama Y: Effects of cycloheximide and actinomycin $\mathrm{D}$ on radiation-induced apoptotic cell death in the developing mouse cerebellum. Int J Radiat Biol 61: 669-674, 1992.
61. Palayoor ST, Macklis RM, Bump EA and Coleman CN: Modulation of radiation-induced apoptosis and G2/M block in murine T-lymphoma cells. Radiat Res 141: 235-243, 1995.

62. Ling CC, Chen $\mathrm{CH}$ and Li WX: Apoptosis induced at different dose rates: implication for the shoulder region of cell survival curves. Radiother Oncol 32: 129-136, 1994

63. Abend M, Rhein A, Gilbertz KP,Blakely WF and Van Beuningen D: Correlation of micronucleus and apoptosis assays with reproductive cell death. Int J Radiat Biol 67: 315-326, 1995.

64. Brown DG, Sun XM and Cohen GM: Dexamethasone-induced apoptosis involves cleavage of DNA to large fragments prior to internucleosomal fragmentation. J Biol Chem 268: 3037-3039, 1993.

65. Elledge SJ: Cell cycle checkpoints: preventing an identity crisis. Science 274: 1664-1672, 1996

66. Candeias SM, Durum SK and Muegge K: p53-dependent apoptosis and transcription of p21waf/cip1/sdil in SCID mice following gamma-irradiation. Biochimie 79: 607-612, 1997.

67. Mountz JD, Wu J, Zhou T and Hsu HC: Cell death and longevity: implications of Fas-mediated apoptosis in T-cell senescence. Immunol Rev 160: 19-30, 1997.

68. Song Q, Burrows SR, Smith G, et al: Interleukin-1 betaconverting enzyme-like protease cleaves DNA-dependent protein kinase in cytotoxic T cell killing. J Exp Med 184: 619-626, 1996

69. Wyllie AH, Kerr JF and Currie AR: Cell death: the significance of apoptosis. Int Rev Cytol 68: 251-306, 1980.

70. Paulovich AG and Hartwell LH: A checkpoint regulates the rate of progression through $\mathrm{S}$ phase in $\mathrm{S}$. cerevisiae in response to DNA damage. Cell 82: 841-847, 1995.

71. Burma S and Chen DJ: Role of DNA-PK in the cellular response to DNA double-strand breaks. DNA Repair (Amst) 3: 909-918, 2004.

72. Rothkamm K and Lobrich M: Misrepair of radiation-induced DNA double-strand breaks and its relevance for tumorigenesis and cancer treatment. (Review) Int J Oncol 21: 433-440, 2002. 